\title{
Biogas Production from Anaerobic Digestion of Different Biodegradable Materials
}

\author{
Tika Sapkota $^{1}$, Jagannath Aryal ${ }^{1}$, Samir Thapa ${ }^{2}$ and Amrit B. Karki ${ }^{3}$ \\ ${ }^{1}$ Central Department of Environmental Science \\ Tribhuvan University, Kirtipur, Kathmandu \\ ${ }^{2}$ Alternative Energy Promotion Centre, Government of Nepal \\ Khumaltar, Lalitpur \\ ${ }^{3}$ Nepal Academy of Science and Technology (NAST) \\ Khumaltar, Laltipur \\ e-mail: tika.sapkota@gmail.com
}

\begin{abstract}
This study presents the feasibility of different biodegradable materials such as kitchen wastes, water hyacinth (Eichhornia sp.), green garden grass, banana (Musa acuminate) bases, Banmara (Eupatorium adenophorum) and cabbage leaves (Brassica oleracea var. capitata) for biogas production. The experiment was conducted using 0.05 $\mathrm{m} 3$ anaerobic bioreactor of ARTI model compact biogas technology under ambient temperature condition in Kathmandu. The minimum and maximum temperature recorded during the study period (March 1 to July 1, 2009) was ranged from $10^{\circ} \mathrm{C}$ to $33^{\circ} \mathrm{C}$. Total solid was found maximum (39.72 percent) in kitchen waste and minimum in cabbage leaves ( 8.36 percent). Volatile solid was more than 75 percent in all substrates. Organic matter ranged from 34.85 to $68.11 \%$. Similarly, C/N ratio was found maximum (22.57:1) in kitchen waste. Variations were observed in $\mathrm{pH}$ values. It was recorded between 5.7 and 6.8 in the first month but above 7 after second month of the plant installation. Burning of gas was detected after 42 days in cow dung, 52 days in water hyacinth, 80 days in kitchen waste and 70 days in banana base, Banmara, garden grass and cabbage leaves. Similarly, methane concentration after 105 days of plant installation was found to be 53 percent in cow dung, 48.8 percent in kitchen waste, 49.4 percent in water hyacinth, 24.5 percent in banana base, 38.5 percent in Banmara and 41.5 percent in garden grass. Total gas production in four months was found maximum in water hyacinth (45 l/kg TS) and minimum in cabbage (25.78 l/kg TS). The gas production in cow dung, Banana base, Banmara, garden grass and kitchen waste was therefore $41.12 \mathrm{l}, 31.14 \mathrm{l}, 34.02 \mathrm{l}, 27.78 \mathrm{l}$ and $32.12 \mathrm{l}$ per $\mathrm{kg}$ of TS respectively. The purpose of designing this micro ARTI model plant was to test the feasibility of selected biodegradable materials for biogas production to be relevant in household level.
\end{abstract}

Key words: anaerobic digestion, alternative energy resources, biodegradable materials, compact biogas technology

\section{Introduction}

Energy is the fundamental necessity for human life for physiological, mechanical, technological and economical development. Utilization of energy resources is considered as prime indicator for initiation of human civilization and development. The world energy consumption has been increased by 49 percent (1.4 percent per year) from 495 quadrillion Btu in 2007 to 739 quadrillion Btu by 2035 (U.S Energy Information Administration 2010). Energy consumption ratio by fuel type in Nepal reveals that major proportion of energy comes from traditional fuels and less than one percent is contributed by renewable energy resources
(Economic Survey of Nepal 2007/08). Huge use of conventional resources in the world increases the green house gases (GHGs) emission, which is the major cause of global warming and climate change.

Biogas energy is obtained by anaerobic digestion of biodegradable materials due to the activities of methanogenic bacteria. Anaerobic decomposition is generally considered to proceed in three sequential stages: hydrolysis or solubilization phase, acidogenesis or acid producing phase and methanogenesis or methane producing phase (Chawal 1986). Biogas generally composes of methane $50-70 \%$, 
carbon dioxide 30-40\%, hydrogen 5-10\%, nitrogen 0.3\% and hydrogen sulphide in traces (Karki \& Dixit 1984). The factors such as nature of raw materials, temperature inside and outside biodigester, toxicity, food to microorganism ratio, etc. influence microbial process and biogas production. ARTI model compact biogas plant is a biogas technology developed by Dr. Ananda Karve in 2003 in India. It is a floating type of plant consisting of generally of $1.0 \mathrm{~m}^{3}$ bio-digester and $0.75 \mathrm{~m}^{3}$ gas holder and is made of High Density Polyethylene (HDPE) water tank.

Alternative energy is essential to fulfill the demand of energy for industrial and domestic purposes. Many biodegradable materials like kitchen wastes, water hyacinth, vegetable wastes, green garden grass, etc are available in household premises. Utilization of such waste materials plays a vital role to improve the environmental conditions. Most of the biogas plants installed utilize cattle dung with or without human feces as input materials. Hence to increase the scope of biogas technology it necessitates using other alternative feeding materials in biogas plants. Use of the above mentioned materials in biogas plant reduces the environmental problems in one side and in the other side it fulfills the current energy demand of the nation. The main objective of the study is to assess the feasibility of different biodegradable materials for biogas generation.

\section{Study site}

The study was carried out in Swoyambhu, Kathmandu Metropolitan-15 which lies at a mean elevation of about $1300 \mathrm{~m}$ from the sea level. The temperature generally ranges from 19 to $27^{\circ} \mathrm{C}$ in summer and 2 to $20^{\circ} \mathrm{C}$ in winter.

\section{Methodology}

Collection of materials: The feeding materials for the biogas plant were collected from different places of Kathmandu valley. Cow dung and kitchen wastes were collected from Jagadal Gand, Chhauni; water hyacinth from Balkumari, Lalitpur; green grasses from Swoyambhu, cabbage leaves from vegetables markets in Kalimati, and Pseudo-banana stem from Chhauni, Kathmandu.

Design and construction of plant: The bioreactor was designed based on ARTI model. Capacities of bioreactor and gas holder were $0.050 \mathrm{~m}^{3}$ and $0.030 \mathrm{~m}^{3}$ respectively. As shown in Fig 1, the top of a $50 \mathrm{l}$ drum was cut and the lid of $30 \mathrm{l}$ drum was opened and inverted over the $50 \mathrm{l}$ drum. A hole of $5 \mathrm{~cm}$ diameter in the upper side and another of the same diameter at lower end were made in the $50 \mathrm{l}$ drum for inlet and outlet of the substrates. The gas outlet was made at the base of the inverted gas holder and fitted with elbow, nipple, main valve and gas exit pipe. All the joints were made air tight.

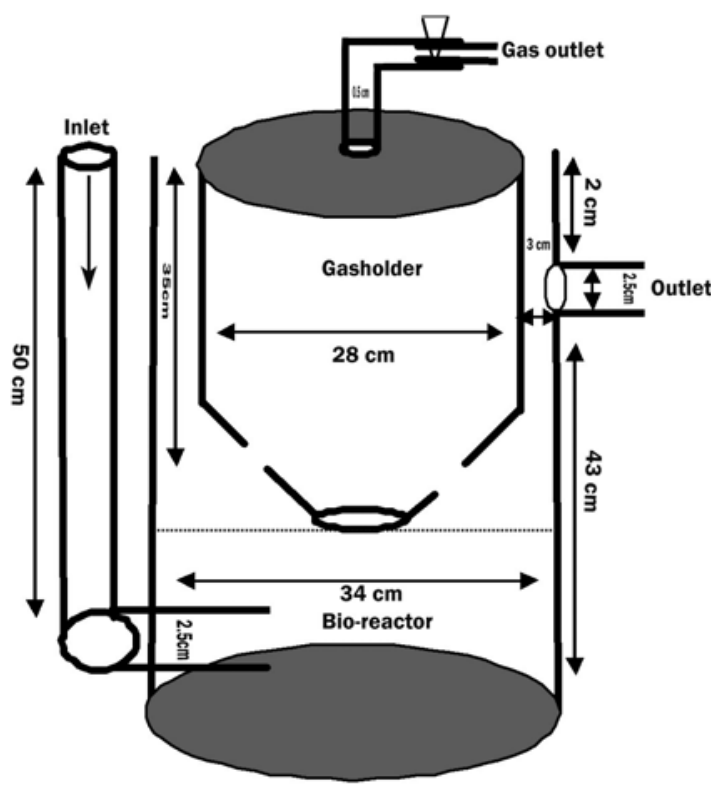

Fig.1. Diagram of $0.5 \mathrm{~m}^{3}$ ARTI model bioreactor used in the study

Laboratory analysis: The physico-chemical parameters such as total solid, volatile solid, $\mathrm{pH}$, organic matter, nitrogen and phosphorus were determined at the laboratory of the Central Department of Environmental Science, Tribhuvan University, Kirtipur by adopting standard methods.

Measurement of temperature: Outside and inside temperature of the bioreactor was measured using laboratory thermometer thrice a day (6:00 am, 12:00 noon and 8:00 pm).

Gas burning test: Gas burning test was done by means of biogas burner fitted in gas outlet.

Determination of methane content: The content of methane and carbon-dioxide in the biogas was determined by Biogas Analyzer Gas Board-3200P. 
Measurement of volume of gas: Volume of the newly produced gas was determined by measuring the height of the gas holder at an interval of ten days.

\section{Results and Discussion}

Temperature records: The temperature of experimental site ranged from $10^{\circ} \mathrm{C}$ to $26^{\circ} \mathrm{C}$ at $6: 00$ am and $23^{\circ} \mathrm{C}$ to $33^{\circ} \mathrm{C}$ at $12: 00$ noon and $22^{\circ} \mathrm{C}$ to $29^{\circ} \mathrm{C}$ at $8: 00 \mathrm{pm}$ during

Table 1. Temperature inside and outside the bio- digester
March 1 to July 1, 2012 of study period. The temperature of experimental site in a day ranged from 12-23$22^{\circ} \mathrm{C}$ to $17-28-26^{\circ} \mathrm{C}$ in first two months and $19-32-31^{\circ} \mathrm{C}$ to $26-33-29^{\circ} \mathrm{C}$ in last two months. It is known that optimum gas production takes place in the mesophilic range between $25^{\circ} \mathrm{C}$ to $30^{\circ} \mathrm{C}(\mathrm{CMS} / \mathrm{FAO}, 1996)$ but the temperature during the study period was found to be less for the optimum amount of gas production (Table 1).

\begin{tabular}{l|c|c|c|c|c|c}
\hline \multirow{2}{*}{ Date } & \multicolumn{2}{|c|}{ At 6:00 am } & \multicolumn{2}{c|}{ At 2:00 pm } & \multicolumn{2}{c}{ At 8:00 pm } \\
\cline { 2 - 6 } & $\begin{array}{c}\text { Outside } \\
\text { digester }\end{array}$ & $\begin{array}{c}\text { Inside } \\
\text { digester }\end{array}$ & $\begin{array}{c}\text { Outside } \\
\text { digester }\end{array}$ & $\begin{array}{c}\text { Inside } \\
\text { digester }\end{array}$ & $\begin{array}{c}\text { Outside } \\
\text { digester }\end{array}$ & $\begin{array}{c}\text { Inside } \\
\text { digester }\end{array}$ \\
\hline $1^{\text {st }}$ March 2009 & $10^{\circ} \mathrm{C}$ & $12^{0} \mathrm{C}$ & $27^{0} \mathrm{C}$ & $24^{0} \mathrm{C}$ & $24^{0} \mathrm{C}$ & $23^{0} \mathrm{C}$ \\
$1^{\text {st }}$ April 2009 & $14^{0} \mathrm{C}$ & $15^{0} \mathrm{C}$ & $29^{0} \mathrm{C}$ & $27^{0} \mathrm{C}$ & $27^{0} \mathrm{C}$ & $25^{0} \mathrm{C}$ \\
$1^{\text {st }}$ May 2009 & $24^{0} \mathrm{C}$ & $22^{0} \mathrm{C}$ & $32^{0} \mathrm{C}$ & $30^{\circ} \mathrm{C}$ & $30^{0} \mathrm{C}$ & $29^{0} \mathrm{C}$ \\
$1^{\text {st June 2009 }}$ & $24^{0} \mathrm{C}$ & $24^{0} \mathrm{C}$ & $31^{0} \mathrm{C}$ & $30^{\circ} \mathrm{C}$ & $29^{0} \mathrm{C}$ & $28.5^{\circ} \mathrm{C}$ \\
$1^{\text {st July 2009 }}$ & $26^{0} \mathrm{C}$ & $24^{0} \mathrm{C}$ & $30^{0} \mathrm{C}$ & $29^{0} \mathrm{C}$ & $29^{0} \mathrm{C}$ & $28^{\circ} \mathrm{C}$ \\
\hline
\end{tabular}

Little difference was observed in temperature inside and outside the bioreactor. On an average, temperature inside the bioreactor at 6:00 am was found $1-2^{\circ} \mathrm{C}$ more which is nearly equal in day and less by 1 $2^{\circ} \mathrm{C}$ at 8:00 pm in the evening. As methanogens are very sensitive to temperature changes (Bitton 1994), this sudden change in a day affects microbial activities and bio-gas production (Garba 1996). The thinner wall of the bioreactor is the main reason for the fluctuating temperature inside it.

Total and volatile solid: The total solid (TS) was found to be $30.32 \%$ in garden grass, $20 \%$ in cow dung, $8.36 \%$ in cabbage leaves and in the range of $10-20 \%$ in kitchen waste, banana base, water hyacinth and Banmara. An attempt was made to maintain the total solid of each feedstock within the appropriate range (7-10\%) by adding corresponding required amount of water. Volatile solids (VS) in water hyacinth, banana base, garden grass, Banmara and cabbage were found to be $81 \%, 90 \%, 89 \%, 84.5 \%$ and $90 \%$ respectively. Volatile solid content in feedstock revealed that all selected materials used in this experiment were feasible and suitable for biogas production.

Carbon and nitrogen content: Carbon was found at 27.3\%, 39.49\%, 20.22\%, 29.71\%, 27.81\%, 31.60\% and $28.76 \%$ in cow dung, kitchen waste, water hyacinth, banana base, Banmara, garden grass and cabbage respectively. Nitrogen content was found maximum in Banmara (6.52) and minimum in kitchen waste (1.75).
Nitrogen was detected high in all feeding materials because they were collected from polluted areas. Nature of the substrates had been considered the main factor affecting microbial activities and biogas production. In the anaerobic digestion, microorganisms commonly use carbon as a source of energy for their growth and nitrogen to build their cell structures.

Organic matter: It was found maximum (68.1\%) in kitchen waste and minimum (34.85\%) in water hyacinth. Organic matter content(O.M\%) in cow dung, banana base, Banmara, garden grass and cabbage leaves was found to be $48.60 \%, 51.22 \%, 47.94 \%, 54.47 \%$ and $49.58 \%$ respectively. Maximum amount of organic matter in kitchen waste might be due to the presence of high glucose.

C/N ratio: The carbon to nitrogen ratio $(\mathrm{C} / \mathrm{N})$ was found to be 22.57:1 in kitchen waste, 5.24:1 in water hyacinth and 4.26:1 in Banmara. Optimum C: $\mathrm{N}$ ratio wasconsidered to be 20-30:1 in approx. (Anunputtikul 2004). In this experiment, $C: \mathrm{N}$ ratio was found to be comparatively less than the optimum range of 20-30:1 in all feeding materials. This was attributed to higher nitrogen content in input materials. Low value of C: $\mathrm{N}$ ratio may affect the microbial growth and biogas production.

Phosphorous: Phosphorus content was found to be 23.5, 18.0, 14.0, 12.1 and 20.0 ppm in hyacinth, banana 
base, Banmara, garden grass and cabbage respectively. Maximum amount of phosphorus in water hyacinth might be due to the organic pollution at its collection site (i.e, a putrefied pond).

Tab le 2. Physico-chemical parameters of all feeding materials

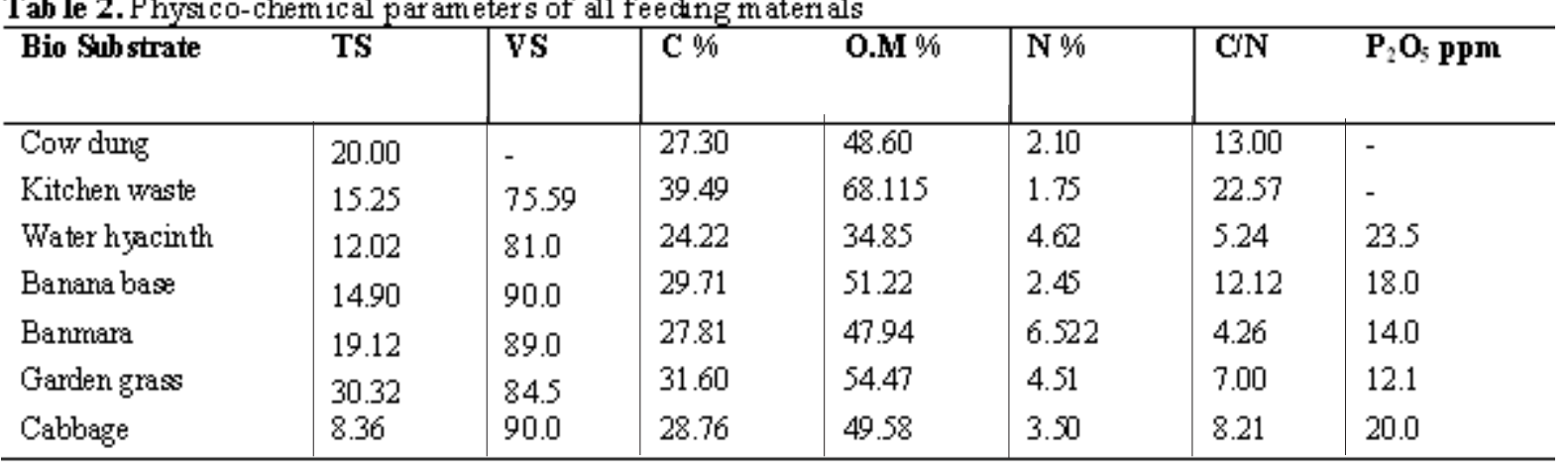

pH: In the first month, the $\mathrm{pH}$ was found maximum (6.88) in cow dung and minimum (5.72) in kitchen waste. In the second month, the $\mathrm{pH}$ of all feedstock was increased. However, in the third month, the $\mathrm{pH}$ in cow dung, water hyacinth and Banmara were found to decrease from 7.02 to $6.45,7.25$ to 6.92 and 7.64 to 7.14 but in the kitchen waste, banana base, garden grass and cabbage leaves, it increased from 6.24 to 7.12, 6.32 to $7.2,6.94$ to 7.24 and 6.28 to 7.38 respectively. In first month, the $\mathrm{pH}$ of all the feedstock was found less than 7 due to acidogenesis process, i.e., conversion of watery slurry into acetic acid, carbon dioxide and hydrogen gas. After second and third month it was increased due to conversion of $\mathrm{H}_{2}, \mathrm{CO}_{2}$ and acetic acid into methane by methanogenic bacteria. Neutrality of $\mathrm{pH}$ in cow dung in early period proved that microbial activities had been completed earlier in the cow dung than in other feeding materials. The $\mathrm{pH}$ value more than 7 in all plants after third month indicated the completion of methanogenic process.

Burning of gas: Burning of gas took place after 42 days of installation in cow dung, followed by water hyacinth in 52 days. In banana base, banmara, garden grass and cabbage, the burning of the gas was observed after 70 days of installation. In kitchen waste, burning of gas started only after 80 days of installation. Biogas mainly consist of carbon dioxide which is noncombustible and methane which is combustible. Burning of gas therefore depends upon the amount of methane production. Initially degradation of wastes produces carbon dioxide, hydrogen and organic acid because of conversion of carbohydrates, proteins and lipids by hydrolytic fermentative bacteria. More production of carbon dioxide than methane, decreased temperature of experimental site and the nature of different biodegradable capacities of feeding materials were some causes for delayed methane production. Plant residue takes longer period for fermentation than animal dung as it contains complex organic matter like cellulose and lignin (Hobson \& Shaw 1971). Naturally cow dung harbors suitable microorganisms for fermentation but the plant wastes take more time for the growth of microorganisms. This was the main reason for earlier production of gas in cow dung plant than in other plants. Cold climatic condition was another important reason for delayed gas production because the growth and activities of methanogenic bacteria would be low in such situation. The particle size of water hyacinth, Banana base, cabbage and garden grass cause slow microbial activities.

Methane content in biogas: Methane content in the biogas was measured twice during the research period. It was found maximum in cow dung and minimum in garden grass when first measured. It was $52 \%$ in cow dung and $1.2 \%$ only in green grasses. In kitchen waste, water hyacinth, banana base, Banmara and cabbage it was $24 \%, 47.5 \%, 15 \%, 30 \%$ and $14.1 \%$ respectively. After one month of the first measurement, methane was found to be increased in all plants. In cow dung, there was small increment (52 to $53 \%$ ) whereas in kitchen waste, it was 24 to $8.8 \%$. The amount of methane in a biogas depends on the microbial process for degradation of the substrates. The first step is hydrolysis in which hydrolytic fermentative bacteria break the organic polymers into organic acid and alcohol; second step is acidogenesis in which 
Tika Sapkota et al./Biogas Production from.........

facultative anaerobic and hydrogen producing acidogenic bacteria convert the simpler organic materials into acetate, hydrogen and carbon dioxide and the last step is methanogenesis in which methanogens convert acetic acid, hydrogen and carbon-dioxide into methane (Chawal 1986). The content of methane (52\%) in cow dung after 75 days of plant installation and less in other materials indicated the early microbial completion in cow dung plant. However, in other plants, hydrolysis and acidogenesis processes were ongoing in initial step. Increment in methane content in all plants after the third month of installation indicated the completion of hydrolysis and acidogenesis process. So, acetic acid, carbon dioxide and hydrogen had been converted into methane by methanogens. However, methane was found comparatively less than similar studies in all plants. This might be due to the slow microbial process, low temperature of experimental site and amount of nutrients like organic matter and nitrogen contents in feeding materials.

Amount of biogas production: After 120 days of plant installation, biogas production in cow dung, kitchen waste, water hyacinth, banana base, Banmara, garden grass and cabbage were $41.12 \mathrm{l} / \mathrm{kg}, 32.12 \mathrm{l} / \mathrm{kg}$, $45 \mathrm{l} / \mathrm{kg}$, $31.14 \mathrm{l} / \mathrm{kg}, 34.02 \mathrm{l} / \mathrm{kg}, 27.78 \mathrm{l} / \mathrm{kg}$, and $25.78 \mathrm{l} / \mathrm{kg}$ of total solids (TS) respectively. Among the seven plants, water hyacinth generated maximum and cabbage produced minimum amount of biogas.

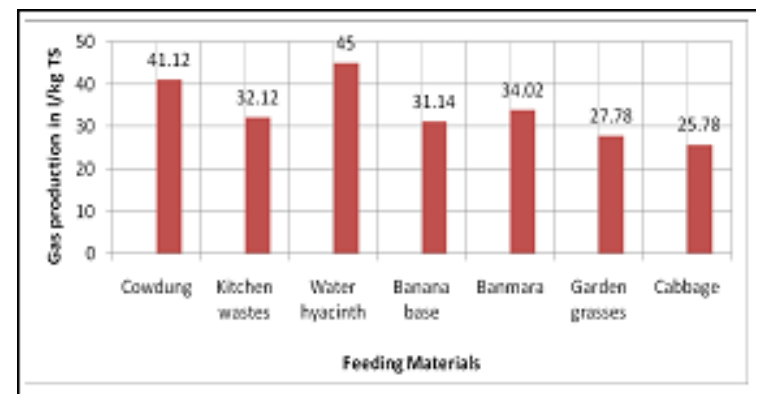

Fig.2. Gas production after 120 days in different plants

Kitchen waste produced more gas than cow dung due to easily degradable materials like carbohydrates, proteins, fats than cellulose and hemicellulose (Yeole 1984, cited in Dhital 2004). In this study, however, the result is reverse. This might be due to longer period of fermentation in kitchen waste than cow dung. Similarly other plant residues such as water hyacinth, Banana base, garden grass and cabbage produced less biogas than cow dung which may be due to the presence of lignin, cellulose and hemi-cellulose resulting in the longer period of fermentation than animal manure (Hobson \& Shaw 1971). Increment of methane content after 75 to 105 days of installation indicated that retention time was still incomplete in kitchen waste, banana base, Banmara, garden grass and cabbage. There might be accumulation of more gas if the study would be pursued for long period of time. Low temperatures of experimental site, large pieces of feeding materials, less carbon to nitrogen ratio were the main causes for less gas production. Plant residue requires longer period of fermentation than animal dung. This was the main cause of slower gas production in all plant stations than in that of cow dung. There was four centimeter difference in the radius of bio digester and gasholder and nearly 32\% of the surface area of the digester was exposed to atmosphere which caused nearly 32\% reductions in total gas accumulation. Moreover, there was leakage of gas through the wall of gas holder and gas outlet joints. The above mentioned factors were the main reasons for less gas production in all plants although the total gas production in all feeding materials were less than those observed in similar studies before. However, it can still be claimed that materials like water hyacinth, Banmara, banana base, garden grass, kitchen wastes and cabbage leaves are feasible and suitable for biogas production because they produced nearly equal amount of biogas compared to cow dung plant.

Feasibility of micro size of ARTI model: According to the promoters of ARTI model, it required more than four $\mathrm{kg}$ of kitchen waste to produce $700 \mathrm{l}$ gas in a day. For an average household it is not possible to avail more than $4 \mathrm{~kg}$ of kitchen waste per day for biogas production. This study was carried in reduced size of ARTI model bioreactor which was 95\% smaller than the standard model that required less than one kilogram of kitchen waste for daily feeding and the gas could used only for experimental purpose.

Role in environmental conservation: Abruptly increasing human population is responsible to generate various types of organic wastes that pollute environment in an alarming rate in one hand and in other hand energy scarcity has also been rapidly increasing. Under these circumstances, biogas would be an environment friendly effective sustainable solution for the management of such wastes at 
household as well community level along with production of biogas energy. Materials like water hyacinth, Banmara, garden grass, banana base, vegetable wastes, etc can be used as feeding materials for biogas production. Water hyacinth covers the surface of standing water like pond and lakes and pollutes the aquatic ecosystem. Banmara as an obnoxious weed has been devastating the crop production especially in hilly region. Garden grasses deteriorate the scenery beauty of environment and damage other useful plant crops. Disposal of kitchen and vegetable wastes including municipal solid waste are serious problem in urban areas. Proper utilization of the above mentioned waste materials as a biosubstrate has two advantages: (i) generation of biogas energy as an alternative energy sources for cooking and lighting and (ii) mitigation of the environmental problems to a greater extent. Environmental problems are also arising due to continued use of chemical fertilizers. Biogas system can therefore generate important bio- fertilizers in the form of bio- slurry. Bio-fertilizer can then help in both increasing the crop production and protecting the environment. It is certain that conventional energy sources will be finished in the near the future and will not be available for the future generation. To save these resources for the future generation, uses of alternative and renewable sources of energy is compulsory and obligatory. Biogas energy is an alternative resource because of easily availability of raw materials, easy and efficient technology and most of the people use this energy for domestic purposes for heating, cooking and lighting. Thus, it has important role for the conservation of the environment.

\section{Acknowledgements}

The authors would like to thank Alternative Energy Promotion Center, Ministry of Environment, Government of Nepal (AEPC/MoE/GoV) for financial support to carry out this dissertation research work and Central Department of Environmental Science, Tribhuvan University (CDES/TU) for providing laboratory facilities.

\section{References}

Aiman, S., T. Lindajati and P. Milono. 1981. Biogas Production from tapioca processing solid waste. In: The first ASEAN seminar-workshop on biogas technology, working group on food waste material Manila, Philippines (Eds. ASEAN Committee on Science and Technology), 36-51pp.
Alaa El-Din, M.N., H.A. Gomma, S.A. El-Shimi and B.E. Ali. 1984. Biogas production from kitchen refuses of army camps of Egypt using a two stage biogas digester. In: Biogas technology: Transfer and diffusion. Elsevier Applied Science, New York, 589-599pp.

Anunputtikul, W. 2004. Biogas production from cassava tubers. Master's thesis. Suranaree University of Technology, Thailand.

Appropriate Rural Technology Institute. 2003. How to build the ARTI biogas digester viewed 12 January 2010, $<$ http://www.howtopedia.org/en>.

Calzada, J.F., E. DePorres, A. Yurrita, M.C. DeArriola, F. DeMicheo, C. Rolz and J.F. Menchu. 1984. Biogas production from coffee pulp juice: one and two-phase systems. Agricultural Wastes 9:217-230.

Carbone, S.R., F.M. Dasilva, C.R.G.Tavares, and B.P. Dias Filho. 2002. Bacterial population of a two-phase anaerobic digestion process treating effluent of cassava starch factory. Environmental Technology 23:591-597.

Chawal, O.P. 1986. Advances in biogas technology. Publication and Information Division, Indian Council of Agricultural Research, New Delhi.

Chhatwal, G.R. 1995. Textbook of biotechnology. Anmol Publication, Pvt. Ltd., New Delhi.

FAO/CMS. 1996. Biogas technology: A training manual for extension. Consolidated Management Services Nepal (P) Ltd.

Karki, A.B. 2000. Training manual in biogas technology for the trainers of junior biogas technology. Biogas Support Programme-Nepal.

Karki, A.B. and K. Dixit. 1984. Biogas field book Sahayogi Press, Kathamandu, Nepal.

Karki, A.B., J.N. Shrestha, S. Bajgain and I. Sharma. 2009. Biogas-As renewable source of energy in Nepal: Theory and development. Second edition, BSP-Nepal, July.

Ministry of Finance. 2009. Economic survey: Fiscal year 2008/09. Published by Ministry of Finance, Government of Nepal.

U.S Energy Information Administration/International Energy Outlook. 2010. World energy demand and economic outlook, viewed 5 March 2010, < h t t p : / / www.eia.doe.gov/oiaf/ieo/pdf/world.pdf $>$.

U.S Energy Information Administration Independent Statistics and Analysis. 2010. Projections in the annual energy outlook 2011, viewed 17, December 2010 <http://www.eia.doe.gov/forecasts/aeo/ executive_summary.cfm>.

Viswanath, P., S.S. Devi and K. Nand. 1992. Anaerobic digestion of fruit and vegetable processing wastes for biogas production. Bioresearch Technology 40:43-48.

Yadvika, S., T.R. Sreekrishnan, S. Kohil V. Rana. 2004. Enhancement of biogas production from solid substrate using different techniques a-review. Bioresearch Technology 95:1-10. 